Article

\title{
Evaluation on Effects of Climate and Land-Use Changes on Streamflow and Water Quality in the La Buong River Basin, Southern Vietnam
}

\author{
Dao Nguyen Khoi ${ }^{1,2}$, Van Thinh Nguyen ${ }^{3, *}$, Truong Thao Sam ${ }^{1}$ and Pham Thi Thao Nhi ${ }^{1}$ \\ 1 Institute for Computational Science and Technology, Ho Chi Minh City 700000, Vietnam; \\ dnkhoi@hcmus.edu.vn (D.N.K.); sam.tt@icst.org.vn (T.T.S.); nhi.ptt@icst.org.vn (P.T.T.N.) \\ 2 Faculty of Environment, University of Science, Vietnam National University Ho Chi Minh City, Ho Chi Minh \\ City 700000, Vietnam \\ 3 Department of Civil and Environmental Engineering, Seoul National University, Seoul 08826, Korea \\ * Correspondence: vnguyen@snu.ac.kr; Tel.: +82-2-880-7355
}

Received: 1 November 2019; Accepted: 10 December 2019; Published: 16 December 2019

\begin{abstract}
The effects of climate and land-use changes have put intense pressures on water resources with regard to water quantity and quality in the La Buong River Basin, located in Southern Vietnam. Therefore, an estimate of such effects and their consequences on water resources in this area is needed. The aim of this study is to evaluate the segregated and aggregated effects of climate change and land-use change on streamflow and water quality components (sediment and nutrient loads) using the well-known Soils and Water Assessment Tool (SWAT). The SWAT model was carefully calibrated and validated against the observation data before it can be used as a simulation tool to study the impacts of climate and land-use changes on hydrological processes. As a result of this study, it shows a reduction in the wet-season and annual streamflow, and sediment and nutrient loads will be occurred in the study area due to climate change effects, while the streamflow, and sediment and nutrient loads will be increased under the effects of the land-use change. Moreover, the streamflow and water quality components are more sensitive to land-use change than climate change. The results obtained from this study can provide a basic knowledge of the effects of climate and land-use changes on the streamflow and water quality to the local and national authorities for the future development of integrated water resources management in the La Buong River Basin.
\end{abstract}

Keywords: climate change; land-use change; streamflow; sediment; nutrient; SWAT

\section{Introduction}

Over the years, water resources regarding water quantity and quality have been under severe pressures due to the consequences of climate and land-use/land-cover changes, of rapid population growth, and socioeconomic development [1]. Assessment of such effects on water resources becomes a difficult task, because various aspects have to be taken into account, in which the impacts of climate and land-use/land-cover changes are considered as decisive factors [2]. Climate change alters precipitation and temperature, which affect hydrological processes, and, accordingly, the streamflow and sediment and nutrient loads [3]; whereas, land-use/land-cover change can cause changes in the regional hydrological components, such as evapotranspiration, infiltration, interception, groundwater, and surface runoff. For instance, a reduction in precipitation could lead to a decrease in surface runoff, groundwater discharge, and soil water content, while deforestation could lead to a decrease in the evapotranspiration, interception rate, and runoff [4]. Thus, a better understanding of the effects of changing climate and land-use on regional hydrology is pivotal for sustainable water resources management. Moreover, the potential effects of climate change or land-use change on hydrology and 
water quality are remarkable; particularly, the integration of both factors together have significantly accelerated water issues.

Studies on the effects of changing climate and land-use on streamflow and water quality have been extensively carried out by various authors in different countries around the world, such as in Thailand [5], Indonesia [6], China [6], Italy [6], and the United States [6].

Vietnam is considered as a developing country located in the monsoon-influenced tropical climate, and widely cited as one of the most vulnerable countries to climate change [1]. The effects of climate change and land-use change on hydrology have been studied by various authors in different regions of Vietnam [7-9]. However, most of the previous studies have focused on the effects of climate change or land-use change on the hydrology separately, and there are still a few studies that considered a combination of both factors together in Vietnam. For instance, Khoi and Suetsugi [10] investigated the effects of climate and land-use changes on the hydrological processes and sediment yield for the Be River Catchment located in Southern Vietnam, and noted that climate change is a major cause of changes in catchment hydrology. In contrast, Wang et al. [11] demonstrated that land-use/land-cover change is the substantial factor affecting streamflow in the Red River Catchment. In fact, Wang et al. [12] showed that effects of changing climate and land use on hydrology should be investigated on a local scale, because of spatial variation of their impacts on the regional hydrology. Nevertheless, no studies have investigated the aggregated effects of climate and land-use changes on both streamflow and water quality components (sediment, T-N, and T-P loads) in Vietnam.

The objective of this study is to estimate the segregated and aggregated effects of climate change and land-use change on the streamflow, sediment, and nutrient loads in the La Buong River Basin, which is considered as a pilot region of the third largest river basin of Vietnam, the Dong Nai River Basin located in Southern Vietnam. As a result, this study provides important guiding information to decision-makers for a future development plan of integrated water resources management. The common method used for assessing the effects of climate and land-use changes on hydrologic cycle is using a hydrological model, because it can tackle different scenarios studies with regard to the relationships between climate, land-use/land-cover, and hydrology [10]. Since the Soil and Water Assessment Tool (SWAT) model is the most widely used hydrological tool for simulating watershed hydrology and its associated processes in different regions around the world, particularly in Southeast Asia [13], we selected this model for our study.

\section{Study Area}

La Buong River, which has a length of $56 \mathrm{~km}$ and an annual discharge of $412 \times 10^{6} \mathrm{~m}^{3}$, is a tributary of Dong Nai River, and located in downstream Dong Nai River (Figure 1). The La Buong River Basin has a total drainage area of $478.5 \mathrm{~km}^{2}$ with the stream density of $0.67 \mathrm{~km}$ per $\mathrm{km}^{2}$, and an annual average precipitation and temperature of $1800 \mathrm{~mm}$ and $25-26^{\circ} \mathrm{C}$, respectively. Due to the relatively flat terrain and influenced by the tropical monsoon climate, this area is divided into two main seasons; the dry season (November-April) and the rainy season (May-October). Moreover, the morphology of the La Buong River Basin is leaf-shaped, the hydrology is heavy rainfall area, causing flash flooding problems in the center, and upper regions, while the lower part is effected by inundation and tide. This area has relatively fertilized land, in which about $75 \%$ of the catchment area is covered by Rhodic Ferralsols and Ferric Acrisols, and consistent with agricultural development. The cultivated land occupies more than $80 \%$ of the total area. Any shortcomings in land-use planning may result in soil erosion and degradation in this area. 


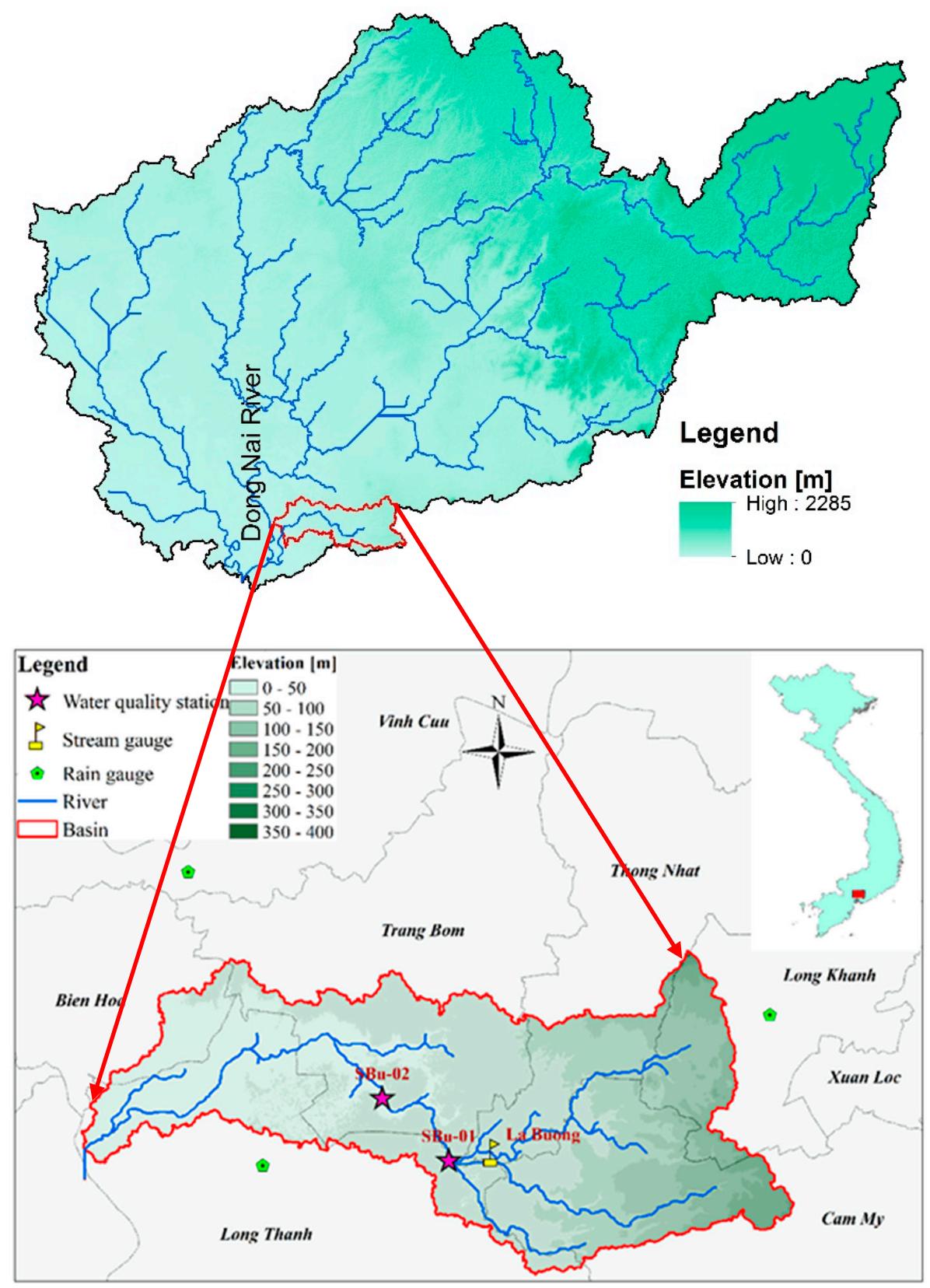

Figure 1. Location of the La Buong River Basin (bottom) that belongs to the Dong Nai River Basin (top).

\section{Methodology}

\subsection{SWAT Model}

The well-known SWAT model was used to simulate the responses of streamflow and water quality components (Total suspended solids (TSS), T-N and T-P loads) in the La Buong River Basin owing to its wide use as a watershed modeling tool, and applied extensively for a broad range of water quality and quantity problems in numerous watershed studies around the world. In SWAT, a basin is divided into sub-basins; subsequently, dividing into hydrological response units (HRUs) based on land-use, soil and slope features. Further details of SWAT for computation of hydrological processes and water quality can be found in Neitsch et al. [14].

In order to set up the SWAT model for the La Buong River Basin, input data included topography, land use, soil, and climate, and was collected from different reliable sources. A digital elevation model (DEM) with a resolution of $12.5 \mathrm{~m}$ was downloaded from the Alaska Satellite Facility (ASF) Distributed 
Active Archive Center (DAAC) to delineate the whole basin and its sub-basins. In this case, the La Buong River Basin was delineated into 32 sub-basins. Land-use data in 2010 and land-use planning data in 2025 with a spatial resolution of $1 \mathrm{~km}$ were collected from the Sub-National Institute of Agricultural Planning and Projection of Vietnam (Sub-NIAPP). Soil data with a spatial resolution of $10 \mathrm{~km}$ were obtained from the Food and Agricultural Organization (FAO) of the United Nations. Based on features of slope, land use, and soil, the study area was delineated into 479 HRUs. Meteorological data from 1981 to 2015 at three stations were collected from the Hydro-Meteorological Data Center of Vietnam (HMDC). Furthermore, monthly observed streamflow data from 1983 to 1993 at the La Buong Station, and water quality data (TSS, T-N, and T-P) from 2010 to 2015 at the Stations "SBu-01" and "SBu-02" were collected from the Department of Natural Resources and Environment of Dong Nai Province for model calibration and validation processes (shown in Figure 1).

SWAT calibration and validation were performed at one hydrological station (La Buong Station) and two water quality stations (SBu-01 and SBu-02). Streamflow was calibrated for the period 1983-1988 and validated for the period 1989-1993 at a monthly time scale. Based on the success of streamflow calibration and validation, the model was continuously calibrated and validated for the simulation of nutrient (T-N and T-P) and sediment (TSS) loads for the period 2010-2015 at a monthly time scale. The model calibration and validation were conducted by the SWAT Calibration and Uncertainty Program (SWAT-CUP) using Sequential Uncertainty Fitting (SUFI-2) due to its efficiency $[15,16]$.

The SWAT performance was assessed by graphical comparison between observed and simulated values and by statistical indices, namely coefficient of determination $\left(R^{2}\right)$ and Nash-Sutcliffe efficiency coefficient (NSE). The $R^{2}$ and NSE are calculated by using the following equations:

$$
\begin{gathered}
R^{2}=\left[\frac{\sum_{i=1}^{n}\left(O_{i}-\bar{O}\right)\left(P_{i}-\bar{P}\right)}{\left[\sum_{i=1}^{n}\left(O_{i}-\bar{O}\right)^{2}\right]^{0.5}\left[\sum_{i=1}^{n}\left(P_{i}-\bar{P}\right)^{2}\right]^{0.5}}\right]^{2} \\
N S E=1-\left[\frac{\sum_{i=1}^{n}\left(O_{i}-P_{i}\right)^{2}}{\sum_{i=1}^{n}\left(O_{i}-\bar{O}\right)^{2}}\right]
\end{gathered}
$$

where $P_{i}$ and $O_{i}$ are the simulated and observed values, $\bar{P}$ and $\bar{O}$ are the mean of the simulated and observed values, and $\mathrm{n}$ is the total number of observations.

According to Moriasi et al. [17], the statistical measures $R^{2}$ and NSE characterized for the performance evaluation criteria of the watershed models are classified as shown in Table 1 below.

Table 1. The statistical criteria $R^{2}$ and NSE measured the performance evaluation of the watershed models [17].

\begin{tabular}{ccccc}
\hline Component & Flow & Sediment & N & P \\
\hline \multirow{2}{*}{ Very good } & $R^{2}>0.85$ & $R^{2}>0.80$ & $R^{2}>0.70$ & $R^{2}>0.80$ \\
& $N S E>0.85$ & $N S E>0.80$ & $N S E>0.70$ & $N S E>0.65$ \\
\hline \multirow{2}{*}{ Good } & $0.80 \leq R^{2} \leq 0.85$ & $0.65 \leq R^{2} \leq 0.80$ & $0.60 \leq R^{2} \leq 0.70$ & $0.65 \leq R^{2} \leq 0.80$ \\
& $0.70 \leq N S E \leq 0.85$ & $0.70 \leq N S E \leq 0.80$ & $0.60 \leq N S E \leq 0.70$ & $0.50 \leq N S E \leq 0.65$ \\
\hline \multirow{2}{*}{ Satisfactory } & $0.70<R^{2}<0.80$ & $0.40<R^{2}<0.65$ & $0.30<R^{2}<0.60$ & $0.40<R^{2}<0.65$ \\
& $0.55<N S E<0.70$ & $0.45<N S E<0.70$ & $0.35<N S E<0.60$ & $0.40<N S E<0.50$ \\
\hline \multirow{2}{*}{ Not satisfactory } & $R^{2} \leq 0.70$ & $R^{2} \leq 0.4$ & $R^{2} \leq 0.30$ & $R^{2} \leq 0.4$ \\
& $N S E \leq 0.55$ & $N S E \leq 0.45$ & $N S E \leq 0.35$ & $N S E \leq 0.4$ \\
\hline
\end{tabular}




\subsection{Climate Change Scenarios}

Climate change scenarios were downscaled from different General Circulation Models (GCMs) obtained from CMIP5 data set, as shown in Table 2. There are many statistical downscaling techniques, such as SDSM, ASD, delta change methods, etc.; among them, LARS-WG developed by Semenov and Stratonovitch [18] was selected for this study, because it can provide a better performance on reproducing monthly meteorological variables than other statistical downscaling techniques, such as SDSM, ASD, and delta change methods [19]. Basically, LARS-WG uses observed meteorological data (daily rainfall, temperature) from a specified site to estimate a set of parameters for fitting probability distributions, which is then used to generate synthetic weather time series of a tributary length by randomly selecting values from appropriate distributions [20]. More information about the LARS-WG tool can be found in [18]. The climate change scenarios for the study area were developed for the near-future period 2021-2050 under the emission scenarios RCP4.5 and RCP8.5.

Table 2. List of five GCMs incorporated in LARS-WG.

\begin{tabular}{ccccc}
\hline No. & Centre & Country & GCM & Resolution \\
\hline 1 & $\begin{array}{c}\text { National Oceanic and } \\
\text { Atmospheric Administration } \\
(\text { NOAA), Geophysical Fluid } \\
\text { Dynamics Laboratory }\end{array}$ & United States & GFDL-CM3 & $2 \times 2.5^{\circ}$ \\
\hline 2 & $\begin{array}{c}\text { European Centre for } \\
\text { Medium-Range Weather } \\
\text { Forecasts }\end{array}$ & Europe & EC-EARTH & $1.1215 \times 1.125^{\circ}$ \\
\hline 3 & UK Met. Office & United Kingdom & HadGEM2-ES & $1.25 \times 1.875^{\circ}$ \\
\hline 4 & $\begin{array}{c}\text { Meteorological Research } \\
\text { Institute }\end{array}$ & Japan & MIROC5 & $1.4008 \times 1.40625^{\circ}$ \\
\hline 5 & $\begin{array}{c}\text { Max-Planck Institute for } \\
\text { Meteorology }\end{array}$ & Germany & MPI-ESM-MR & $1.8653 \times 1.875^{\circ}$ \\
\hline
\end{tabular}

In order to investigate the segregated and aggregated impacts of climate change and land-use change on streamflow, TSS, and nutrient loads, we first evaluated the impacts of climate change and land-use change on streamflow, TSS, and nutrient loads, separately. Then, the impacts caused by an accumulation of both climate change and land-use change were implemented, aggregately.

The well-calibrated SWAT model was used as a simulation tool to calculate various cases at a monthly time scale; and the simulation results were analyzed as the percentage changes (\%) between the baseline and climate and/or land-use change scenarios.

\section{Results and Discussion}

\subsection{Calibration and Validation of SWAT}

Before the SWAT model can be used as a simulation tool for this study, it has to be carefully calibrated and validated against the observation data. Table 3 shows the ranges of parameters in the SWAT model, which were used for the calibration process of the streamflow and water quality (TSS, T-N, and T-P loads) simulations. The SWAT parameters were determined based on the sensitivity analysis using SWAT-CUP [21]. Due to the observation data of water quality components missing for the period from 1983 to 1993, we first performed the calibration and validation of the SWAT model for the streamflow for this period, then the calibration and validation of the water quality parameters for another period from 2010 to 2015 were carried out, because the data of sediment and nutrient loads were observed only during this period. 
Table 3. Calibrated values of SWAT parameters for stream flow and water quality.

\begin{tabular}{|c|c|c|c|}
\hline Parameter & Description of Parameter & Initial Range & Calibrated Value \\
\hline \multicolumn{4}{|c|}{ Parameters used to calibrate streamflow } \\
\hline v_CH_K2 & $\begin{array}{l}\text { Channel effective hydraulic } \\
\text { conductivity }\end{array}$ & $-0.01 \div 500$ & 194 \\
\hline r_CN2 & Initial SCS CN II value & $-0.2 \div 0.2$ & -0.15 \\
\hline v_ESCO & $\begin{array}{l}\text { Soil evaporation compensation } \\
\text { factor }\end{array}$ & $0 \div 1$ & 0.81 \\
\hline v_GWQMN & $\begin{array}{l}\text { Threshold water depth in the } \\
\text { shallow aquifer for flow }\end{array}$ & $0 \div 5000$ & 962 \\
\hline r_REVAPMN & $\begin{array}{l}\text { Threshold water depth in the } \\
\text { shallow aquifer for "revap" }\end{array}$ & $0 \div 1000$ & 757 \\
\hline \multicolumn{4}{|c|}{ Parameters used to calibrate sediment loads } \\
\hline r_SPCON & $\begin{array}{l}\text { Linear parameter for calculating } \\
\text { the maximum amount of sediment } \\
\text { that can be re-entrained during } \\
\text { channel sediment routing }\end{array}$ & $-0.20 \div 0.20$ & -0.13 \\
\hline v_SPEXP & $\begin{array}{l}\text { Exponent parameter for } \\
\text { calculating sediment re-entrained } \\
\text { in channel sediment routing }\end{array}$ & $1 \div 1.5$ & 1.4 \\
\hline r_USLE_P & USLE equation support practice & $-0.20 \div 0.20$ & -0.07 \\
\hline \multicolumn{4}{|c|}{ Parameters used to calibrate nutrient loads } \\
\hline v_LAT_ORGN & Organic $\mathrm{N}$ in the base flow $(\mathrm{mg} / \mathrm{l})$ & $0 \div 200$ & 56 \\
\hline v_N_UPDIS & $\begin{array}{l}\text { Nitrogen uptake distribution } \\
\text { parameter }\end{array}$ & $0 \div 100$ & 2 \\
\hline v_NPERCO & Nitrogen percolation coefficient & $0 \div 1$ & 0.48 \\
\hline v_LAT_ORGP & Organic $P$ in the base flow $(\mathrm{mg} / \mathrm{l})$ & $0 \div 200$ & 97 \\
\hline v_P_UPDIS & $\begin{array}{l}\text { Phosphorus uptake distribution } \\
\text { parameter }\end{array}$ & $0 \div 100$ & 14 \\
\hline v_PPERCO & Phosphorus percolation coefficient & $10 \div 17.5$ & 17 \\
\hline
\end{tabular}

Figure 2 presents a comparison of the streamflow between simulation results and observation data (lower), and in contrast to the precipitation (upper) at the La Buong Station for the calibration period (1983-1988) and validation period (1989-1993). The comparison indicates that the monthly simulated and observed values have a good agreement each other; however, it should state that the simulation still cannot well capture the peak of streamflow in some months during rainy seasons. This can be explained by uneven distribution of rain gauges; particularly, three available rain gauges are located on the border of the study area. In addition, Table 4 shows a summary of the statistical indices $\left(R^{2}\right.$ and $N S E)$ for evaluating the SWAT model performance. It shows that monthly simulated streamflow has been classified in a range from good to very good agreement with the observed data, as the indices $R^{2}$ are 0.79 and 0.87 , and NSE are 0.72 and 0.82 for the calibration and validation periods, respectively. Generally, SWAT has showed a good performance in simulation of streamflow in the study area. 


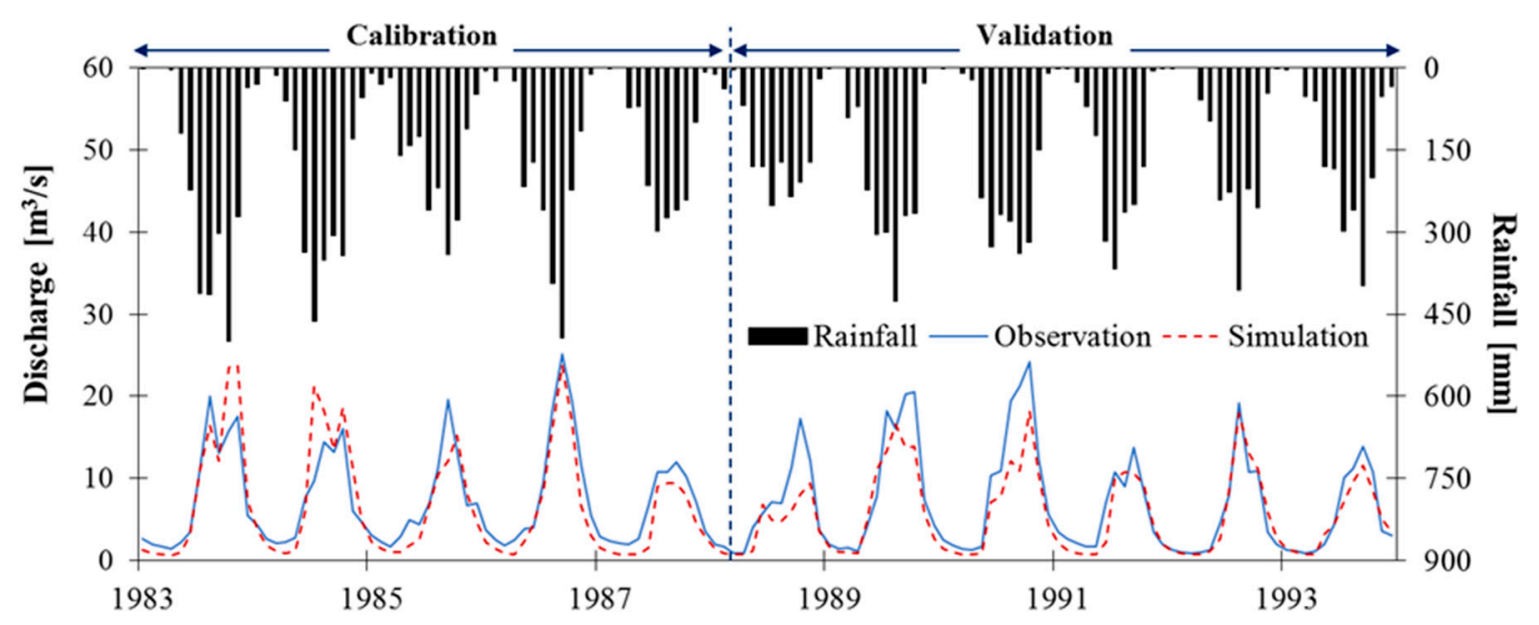

Figure 2. Observed and simulated monthly streamflow for the calibration and validation periods.

Table 4. Statistical evaluation criteria for monthly simulations of flow and water quality.

\begin{tabular}{|c|c|c|c|c|c|c|}
\hline \multirow{2}{*}{ Station } & \multicolumn{3}{|c|}{ Calibration } & \multicolumn{3}{|c|}{ Validation } \\
\hline & Time Period & $R^{2}$ & NSE & Time Period & $R^{2}$ & $N S E$ \\
\hline \multicolumn{7}{|c|}{ Streamflow } \\
\hline La Buong & 1983-1988 & 0.79 & 0.72 & 1989-1993 & 0.87 & 0.82 \\
\hline \multicolumn{7}{|c|}{ TSS load } \\
\hline SBu-01 & 2010-2012 & 0.83 & 0.73 & 2013-2015 & 0.62 & 0.54 \\
\hline SBu-02 & 2010-2012 & 0.75 & 0.75 & 2013-2015 & 0.67 & 0.66 \\
\hline \multicolumn{7}{|c|}{ T-N load } \\
\hline SBu-01 & 2010-2012 & 0.84 & 0.74 & 2013-2015 & 0.71 & 0.62 \\
\hline SBu-02 & 2010-2012 & 0.84 & 0.71 & 2013-2015 & 0.64 & 0.56 \\
\hline \multicolumn{7}{|c|}{ T-P load } \\
\hline SBu-01 & 2010-2012 & 0.72 & 0.56 & 2013-2015 & 0.52 & 0.44 \\
\hline SBu-02 & 2010-2012 & 0.65 & 0.44 & 2013-2015 & 0.51 & 0.40 \\
\hline
\end{tabular}

Figures 3-5 present the comparisons between observed data and simulated results of TSS, T-N, and T-P loads for the calibration period (2010-2012) and validation period (2013-2015) at two gauging stations; namely SBu-01 and SBu-02. As shown in these figures, the SWAT model could reasonably capture the TSS, T-N, and T-P loads for the La Buong River Basin. Moreover, in a comparison of the indices values of $R^{2}$ and NSE from Table 4 obtained from the calibration and validation periods with the statistical criteria in Table 1 [17], it shows that monthly simulations of the TSS, T-N, and T-P loads have been classified in a range from satisfactory to very good agreement with the observed data, as the indices $R^{2}$ and NSE of calibration and validation are ranging from 0.62 to 0.83 and from 0.54 to 0.75 for the TSS; from 0.64 to 0.84 and from 0.56 to 0.74 for the total N; and from 0.51 to 0.72 and from 0.40 to 0.56 for total P, respectively. Only the index value of NSE $(=0.40)$ for T-P for the validation period at the SBu-02 Station has taken the value between "Satisfactory" and "Not satisfactory." Overall, the SWAT model showed a good performance in simulation of the streamflow, TSS, T-N, and T-P loads in the study area. 


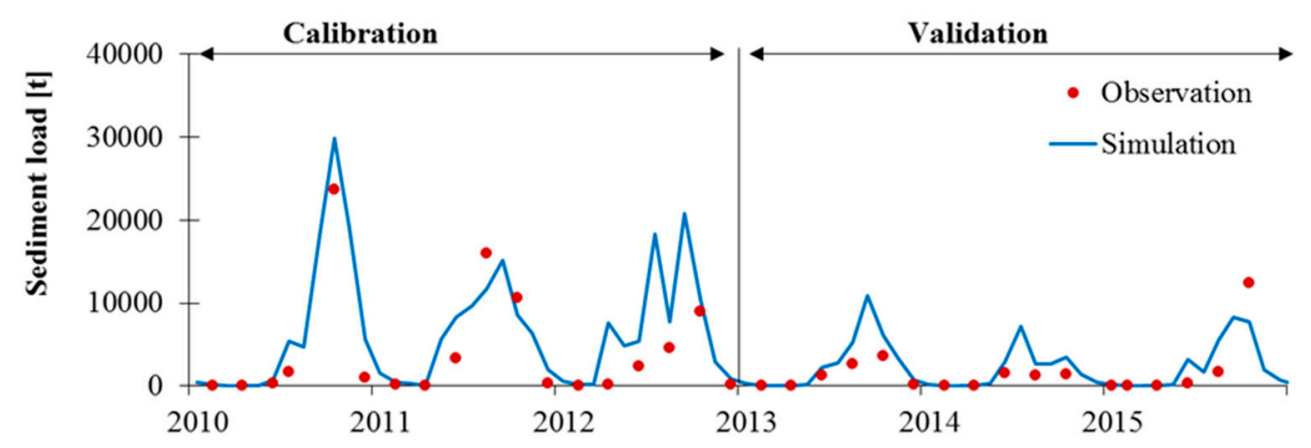

(a) SBu-01 station

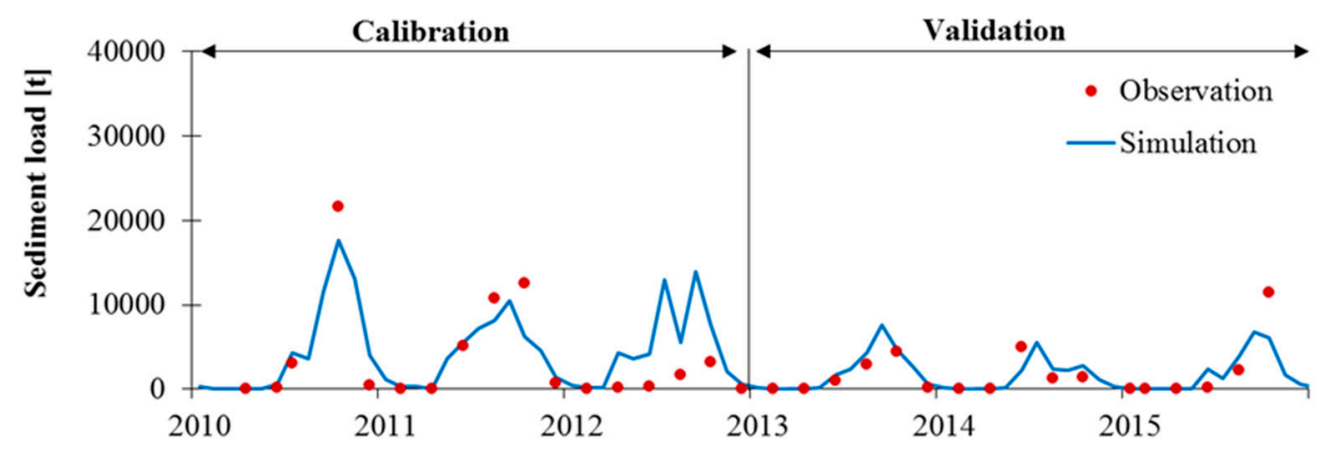

(b) SBu-02 station

Figure 3. Observed and simulated monthly sediment load for the calibration and validation periods.

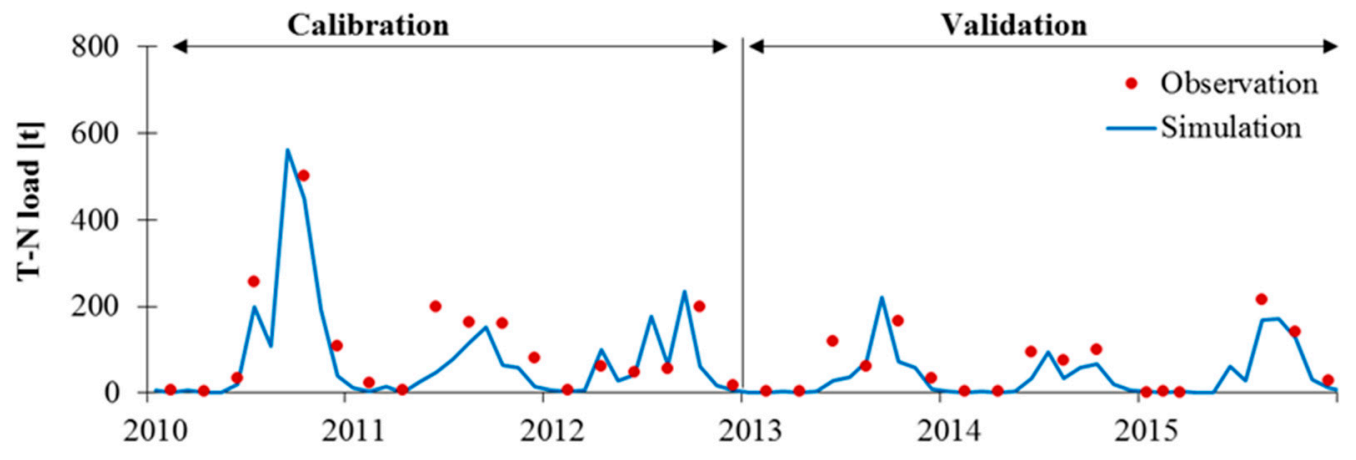

(a) SBu-01 Station

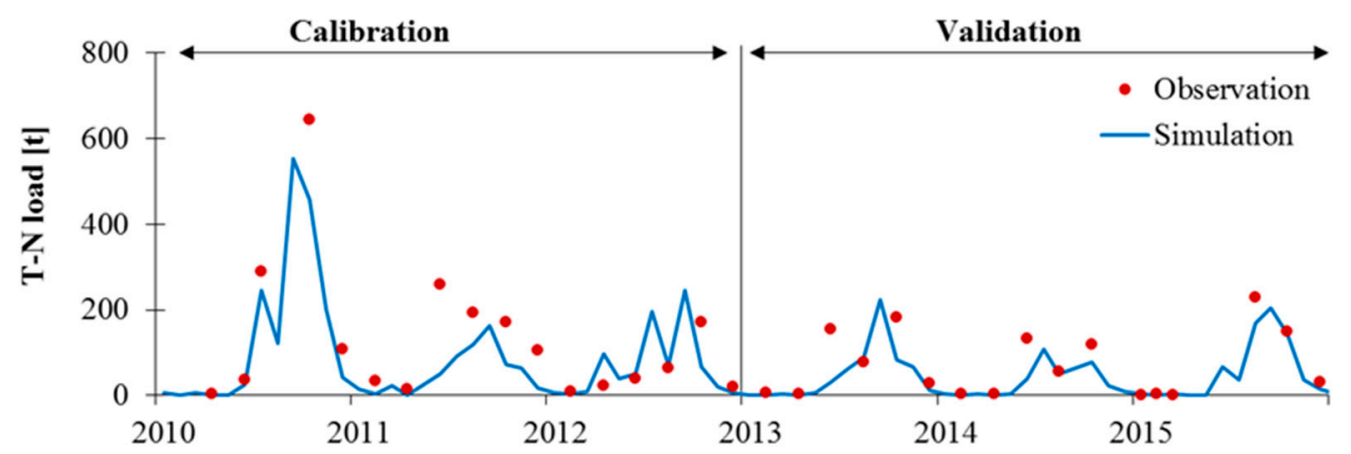

(b) SBu-02 station

Figure 4. Observed and simulated monthly T-N load for the calibration and validation periods. 


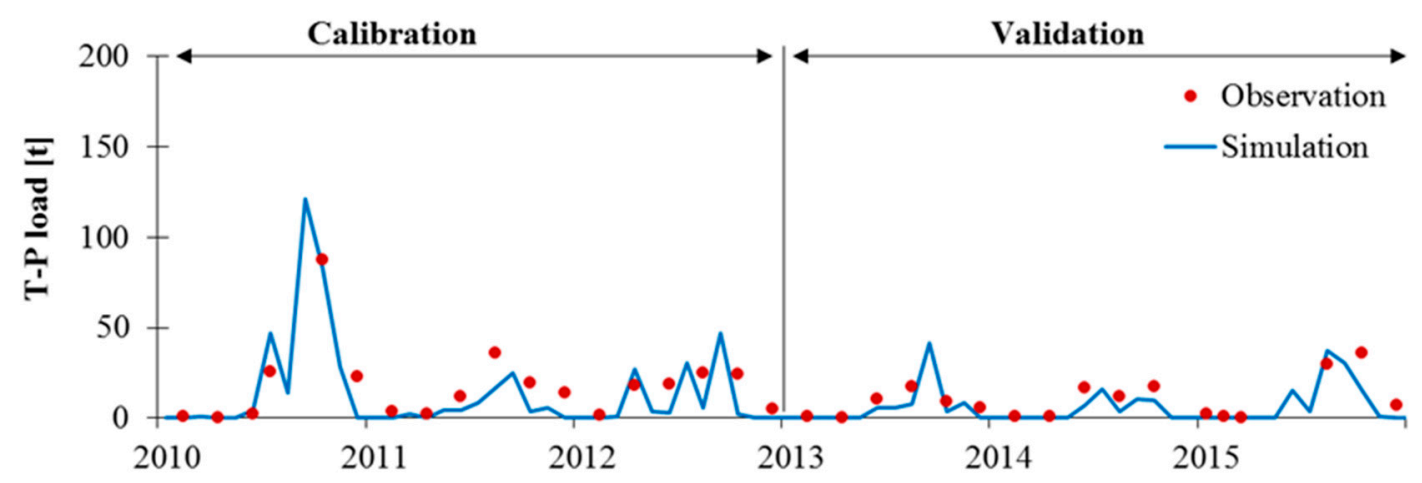

(a) SBu-01 station

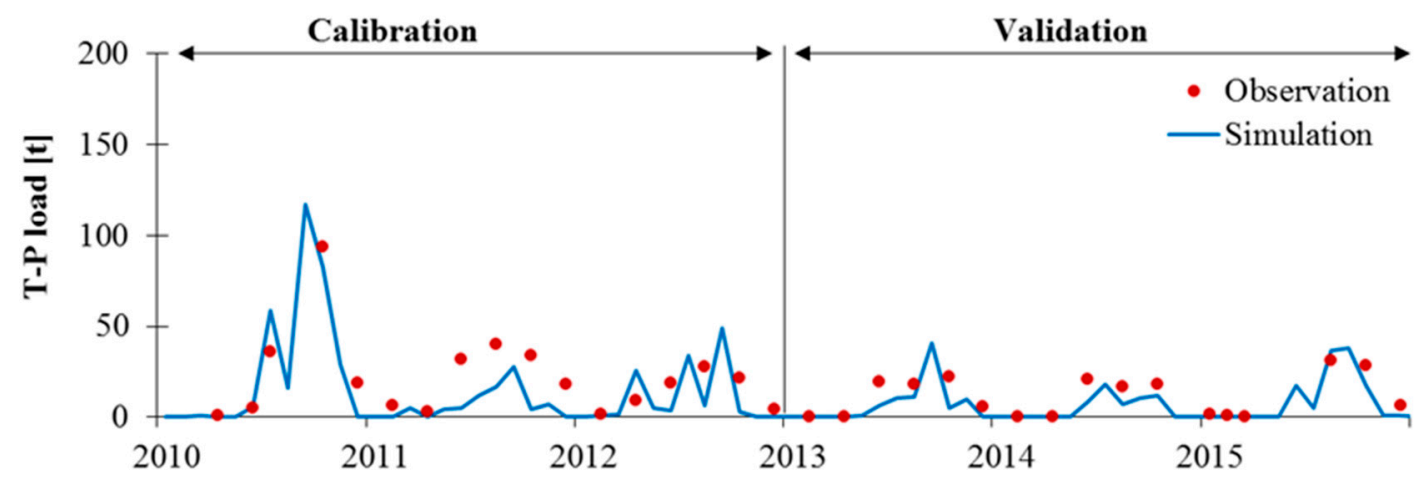

(b) SBu-02 station

Figure 5. Observed and simulated monthly T-P load for the calibration and validation periods.

As mentioned above, the calibration and validation results indicated a satisfactory reliability of the SWAT model in simulations of streamflow, sediment, and nutrient loads in the study area; therefore, we can apply the SWAT model as a simulation tool to study the effects of climate and land-use changes on hydrological processes and water quality in the La Buong River Basin.

\subsection{Evaluation on Effects of Climate Change}

Monthly rainfall data obtained from LARS-WG simulation at three rain-gauged stations, namely Vinh Cuu, Long Khanh, and Long Thanh, surrounding the study area, were evaluated using two statistical indices, including $R^{2}$ and root mean square error (RMSE) for the calibration period (1981-1991) and validation period (1992-2005). Particularly, the values of $R^{2}$ and RMSE are ranged from 0.61 to 0.72 , and from 89 to $95 \mathrm{~mm}$, respectively. Thus, LARS-WG showed satisfactory performance in reproducing monthly rainfall for the study area.

Therefore, LARS-WG can be applied to produce rainfall data for future climate change study. The rainfall data under the emission scenarios RCP4.5 and RCP8.5 for the period 2021-2050 were downscaled from five different GCMs (as shown in Table 2) by using LARS-WG. The annual rainfall is predicted to be decreased slightly by $0.1 \%$ for RCP 4.5 , and $1.1 \%$ for RCP8.5 in the future period 2021-2050. Figure 6a shows seasonal and annual rainfalls obtained from different GCMs, whereby the annual rainfall value is highly varied between each GCM's output; particularly, the annual change in rainfall is varied from $-10.6 \%$ (HadGEM2-ES) to 9.9\% (MIROC5) for RCP4.5; and from $-15.3 \%$ (HadGEM2-ES) to 7.3\% (MPI-ESM-MR) for RCP8.5. Regarding the seasonal change, the rainfall is predicted to be decreased in wet-seasonal, and increased in dry-seasonal under both RCP 4.5 and RCP8.5 scenarios. The decrease in rainfall during the wet season varies from $2.5 \%$ to $2.9 \%$; while the increase in rainfall during the dry season ranges from $9.8 \%$ to $14.3 \%$ for the period $2021-2050$. 
RCP4.5

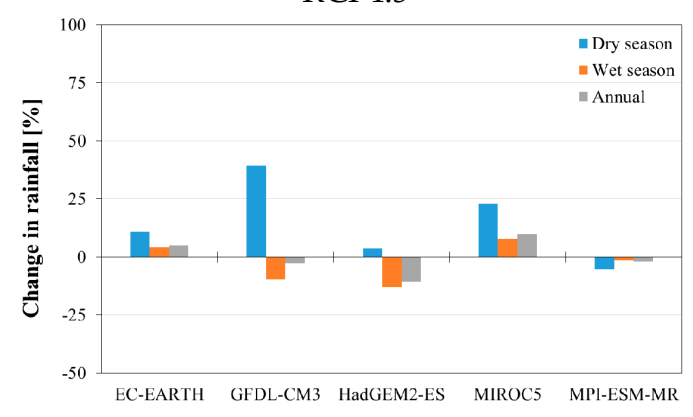

(a) Rainfal
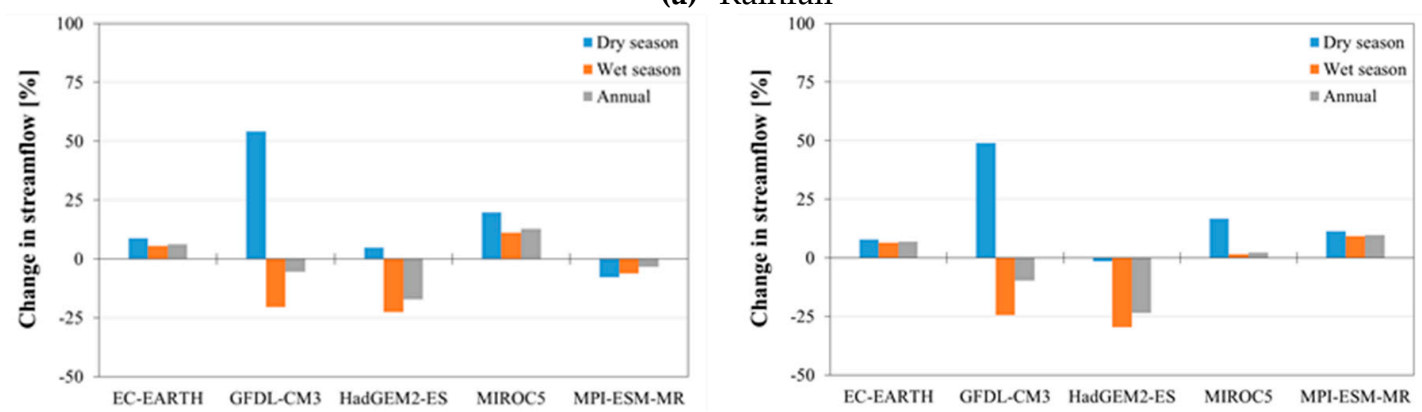

(b) Streamflow
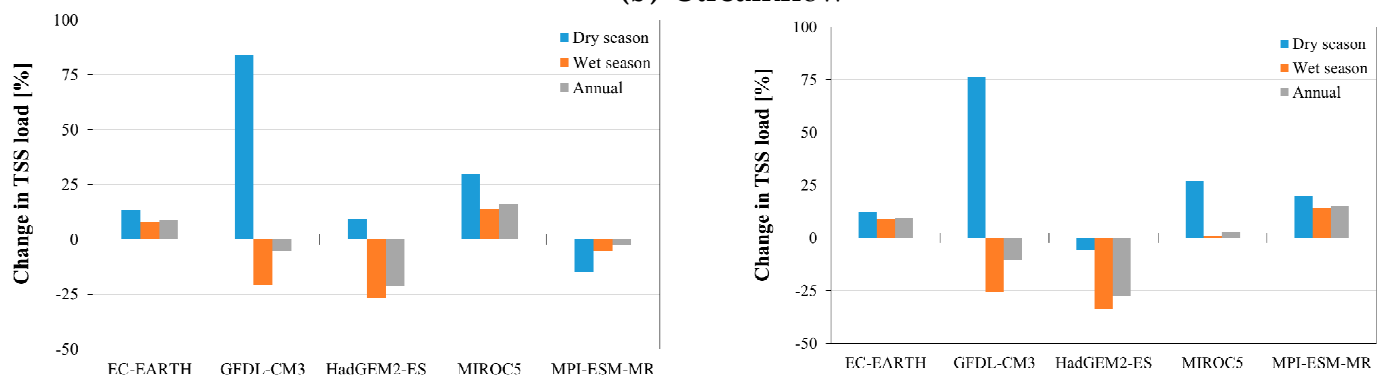

(c) TSS load
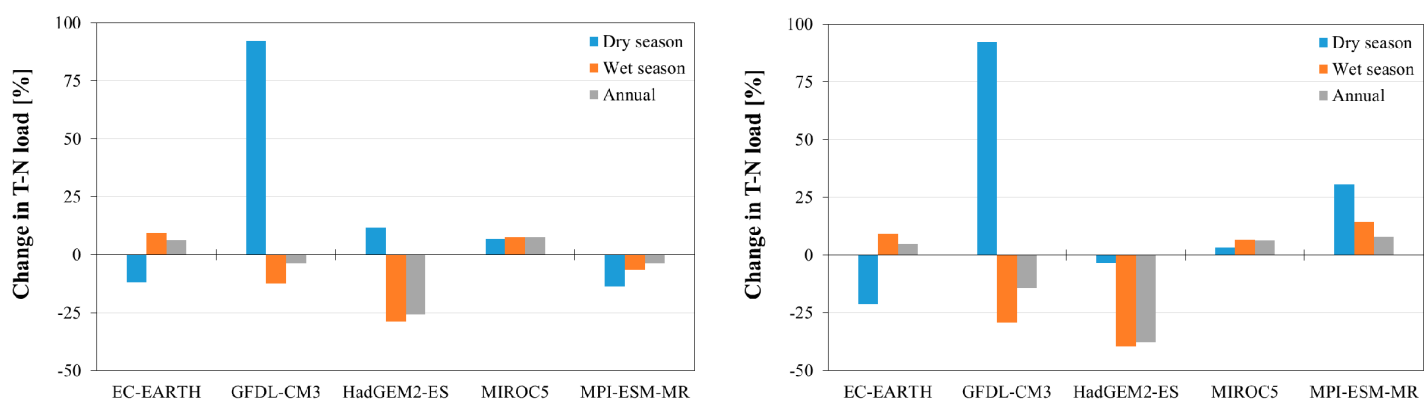

(d) T-N load
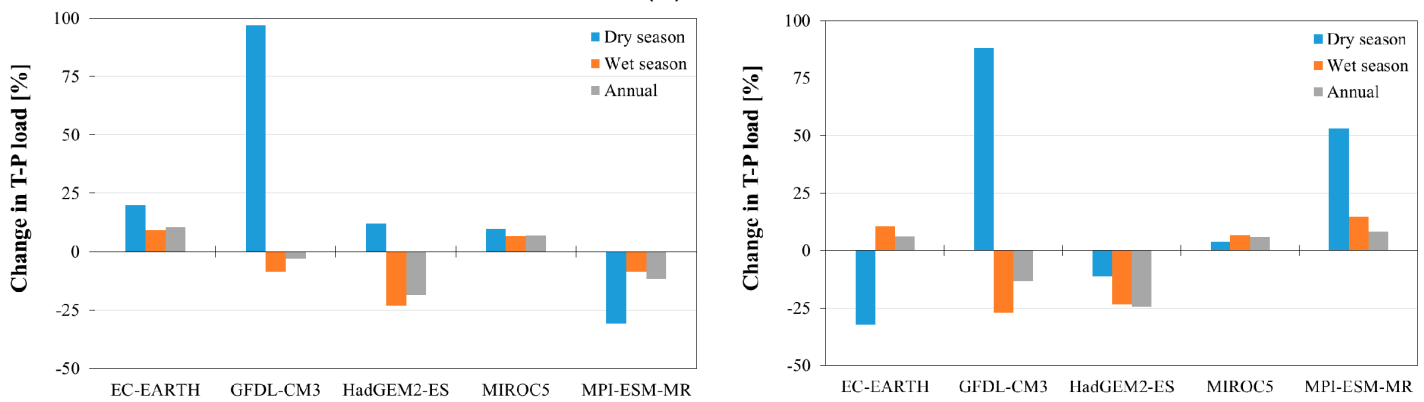

(e) T-P load

Figure 6. Changes in precipitation (a), streamflow (b), TSS load (c), T-N load (d), and T-P load (e) under the RCP4.5 (left) and RCP8.5 (right) scenarios during 2021-2050. 
Figure 6 illustrates the effects of different GCMs on annual and seasonal streamflow, and TSS, T-N, and T-P loads. The tendency of changes in annual and seasonal streamflow, TSS, T-N, and T-P load are in accordance with the tendency of change in rainfall. In particular, following the decrease in annual rainfall, annual streamflow and TSS, T-N, and T-P loads are predicted to be decreased by $1.6 \%$, $0.9 \%, 3.8 \%$, and $3.3 \%$ for RCP 4.5 , and $2.9 \%, 2.2 \%, 6.7 \%$, and $3.5 \%$ for RCP 8.5 , respectively. In case of seasonal change, the decreases in wet-seasonal streamflow, TSS, T-N, and T-P loads are varied from $6.6 \%$ to $7.4 \%, 6.3 \%$ to $7.1 \%, 6.2 \%$ to $7.7 \%$, and $3.8 \%$ to $5 \%$, respectively; and the increases in dry-seasonal streamflow, TSS, T-N, and T-P loads are from $16.1 \%$ to $16.3 \%, 24.3 \%$ to $25.8 \%, 17 \%$ to $20.3 \%$, and $20.3 \%$ to $21.5 \%$, respectively.

The change in streamflow due to the climate change in the La Buong River Basin is in agreement with the findings of previous studies conducted by Sam et al. [22] and Huyen et al. [7] in the Srepok River Basin in the Central Highlands of Vietnam. In particular, Huyen et al. [7] indicated that the annual discharge will be decreased by $1.2 \%$ to $11.1 \%$ under the A1B emission scenario, and increased by $1.8 \%$ to $2.4 \%$ under the A2 emission scenario. Sam et al. [22] presented a decrease of $11.9 \%$ (within the range of $-26.5 \%$ to $-9.8 \%$ ) in the streamflow under the RCP8.5 emission scenario.

\subsection{Evaluation on Effects of Land-Use Change}

In order to evaluate the effects of land-use changes on streamflow and water quality for the La Buong River Basin, two land-use types in 2010 and 2025 (planning) were used as input data to the well-calibrated SWAT model. Figure 7 and Table 5 present the land-use types of the study area in 2010 and 2025, and shows that the main land-use type is agricultural land ( $87 \%$ of the total basin area). Due to demand for local economic development, a shift in crop system has occurred in recent years. Particularly, perennial cropland (cashew and coffee), occupying $21 \%$ of the basin area, are converted to annual cropland.

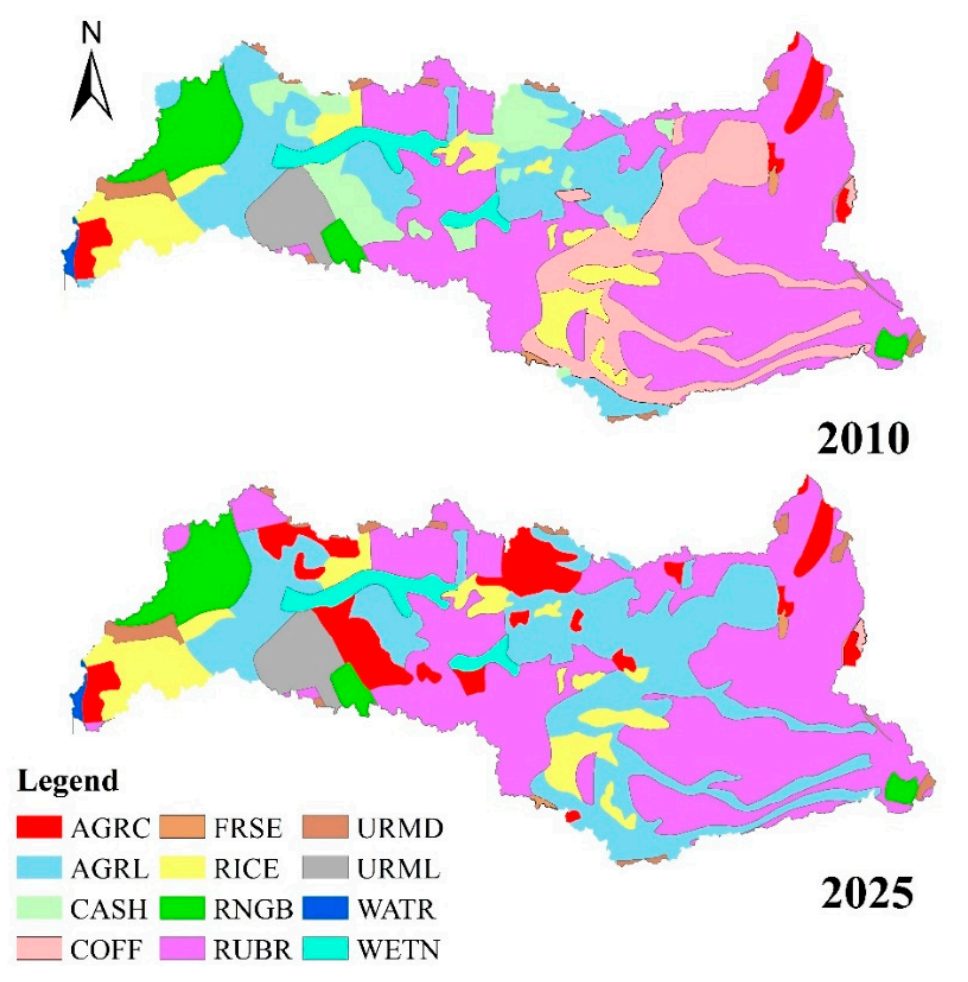

Figure 7. Land use maps of the study area in 2010 and 2025. 
Table 5. Land-use types in 2010 and 2025 (planning) in the La Buong River Catchment.

\begin{tabular}{ccccc}
\hline SWAT Code & Description & $\left.\mathbf{2 0 1 0} \mathbf{( k m}^{\mathbf{2}}\right)$ & $\left.\mathbf{2 0 2 5} \mathbf{( k m}^{\mathbf{2}}\right)$ & Area Change $\mathbf{( k m}^{\mathbf{2}} \mathbf{1}$ \\
\hline WATR & Water & 1 & 1 & 0 \\
\hline AGRL & $\begin{array}{c}\text { Agricultural } \\
\text { land-generic }\end{array}$ & 66.1 & 119.3 & 0 \\
\hline RNGB & Range-brush & 23.1 & 23.1 & -58.9 \\
\hline COFF & Coffee & 59.5 & 0.6 & 29.1 \\
\hline AGRC & $\begin{array}{c}\text { Agricultural } \\
\text { close-grown crops }\end{array}$ & 8.8 & 37.9 & 0 \\
\hline URML & $\begin{array}{c}\text { Urban } \\
\text { medium-low } \\
\text { density }\end{array}$ & 13.2 & 13.2 & 0 \\
\hline RICE & Rice & 35.5 & 35.5 & 0 \\
\hline FRSE & Forest-evergreen & 1.4 & 1.4 & 0 \\
\hline URMD & $\begin{array}{c}\text { Urban medium } \\
\text { density }\end{array}$ & 7.4 & 7.4 & 0 \\
\hline WETN & Wetlands-nonforested & 11.4 & 11.4 & -29.1 \\
\hline CASH & Cashew & 29.1 & 0 & 5.7 \\
\hline RUBR & Rubber & 179 & 184.7 & 0 \\
\hline & Total & 435.5 & 435.5 & \\
\hline & & & & 0 \\
\hline
\end{tabular}

Figure 8 presents the effects of land-use change on annual and seasonal streamflow, and TSS, T-N, and T-P loads. Under the conversion from perennial cropland to annual cropland, the annual and seasonal streamflow, TSS, T-N, and T-P loads are predicted to be increased. In particular, the increases in annual streamflow, TSS, T-N, and T-P loads are $12.9 \%, 14.5 \%, 13.0 \%$, and $14.1 \%$, respectively. In case of seasonal change, the wet-seasonal streamflow, TSS, T-N, and T-P loads are increased by $7.4 \%, 9.3 \%$, $10.2 \%$, and $8.2 \%$, respectively; and the dry-seasonal streamflow, TSS, T-N, and T-P loads are increased by $34.9 \%, 44.6 \%, 51.0 \%$, and $70.6 \%$, respectively.

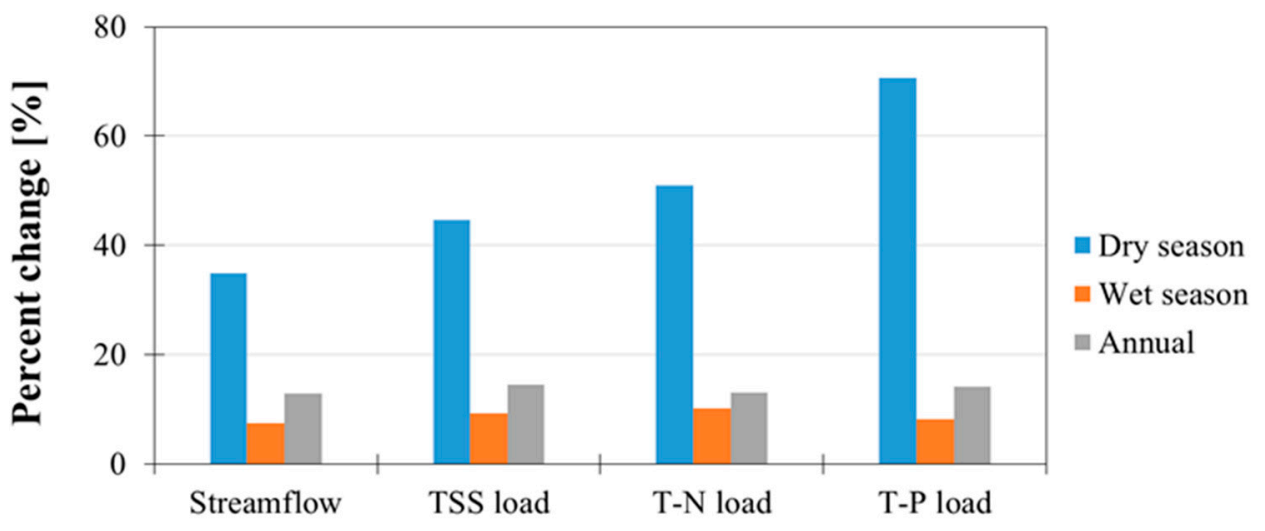

Figure 8. Changes in streamflow, TSS load, T-N load, and T-P load under the impact of land-use change.

The impact of land-use/land-cover change on the streamflow and water quality in different parts of Vietnam has been investigated in several studies. Khoi and Suetsugi [10] reported that a decrease by $16.3 \%$ in forestland leads to increase in streamflow by $0.2 \%$ to $0.4 \%$, and in sediment yield by $1.8 \%$ to 3.0\% in the Be River Basin located in Southern Vietnam. Ngo et al. [8] evaluated that the land-use change impacts streamflow in the Da River Basin located in Northwest Vietnam, and concluded that a conversion from forestland to agricultural and urban lands caused an increase in streamflow. Generally, the change in streamflow and water quality caused by the land-use change in the La Buong 
River Basin is similar to the findings of the previous studies in Vietnam conducted by Khoi and Suetsugi [10] and Ngo et al. [8].

Consequently, the change in land use by changing specific main crops such as changing from perennial crops (cashew and coffee) to annual crops (vegetable, corn, bean, etc.), can directly affect water quality and soil erosion (sediment). The roots of cashew and coffee trees have more potentials in protecting the surface soils than annual crops. In addition, as mentioned above, the TSS, T-N and -P loads are significantly increased (about 35\% to $70 \%$ ) in dry -seasons, which can have substantial effects on water quality in this region. Therefore, the economic evaluations should take into account the costs to deal with water quality and soil erosion issues $([23,24])$ in future land use planning.

\subsection{Evaluation on Aggregated Effects of Climate and Land-Use Change}

To evaluate the aggregated effects of climate change and land-use change on streamflow and water quality parameters (TSS, T-P and T-N loads), the planning land-use data in 2025 in combination with climate change scenarios RCP 4.5, RCP 8.5 during 2021-2050 (as shown in Sections 4.2 and 4.3) were used as input data to the well-calibrated SWAT model. Table 6 shows the percent changes in annual and seasonal streamflow, and TSS, T-N, and T-P loads under the segregated and aggregated impacts of land-use and climate changes. It shows that the streamflow, and water quality components (TSS, T-N, and T-P) are predicted to be significantly increased in dry seasons under segregated and aggregated effects by climate and/or land-use changes. Particularly, in comparison to the effect of climate change, the land-use change plays a substantial role in this increment during dry season; consequently, a combination of both changes in climate and land use will derive in a notable increase in the streamflow $(44.1 \%-51.7 \%)$, TSS (59.3\%-70.3\%), T-N (58.1\%-70.8\%), and T-N $(93.7 \%-96.6 \%)$ for the period 2021-2050. However, the trend of changes in streamflow and water quality components under segregated effects by climate change and land-use change is opposite directions, whereby the streamflow, TSS, T-N, and T-P will be slightly decreased $(-0.9 \%--7.7 \%)$ under effect of climate change, while those are predicted to be increased (7.4\%-14.5\%) under the effect of land-use change in the wet season and annual.

Table 6. Percent changes in annual and seasonal streamflow, TSS load, T-N load, and T-P load under the separated and combined impacts of climate change (CC) and land-use change (LUC) in the La Buong River Basin.

\begin{tabular}{ccccccc}
\hline & & \multicolumn{2}{c}{ CC } & \multicolumn{2}{c}{ LUC } & \multicolumn{2}{c}{ CC + LUC } \\
\cline { 3 - 7 } & & $\boldsymbol{R C P 4 . 5}$ & $\boldsymbol{R C P 8 . 5}$ & & $\boldsymbol{R C P 4 . 5}$ & \multicolumn{1}{c}{$\boldsymbol{R C P 8 . 5}$} \\
\hline \multirow{2}{*}{$\begin{array}{c}\text { Streamflow } \\
(\%)\end{array}$} & Dry season & 16.1 & 16.3 & 34.9 & 51.7 & 44.1 \\
\cline { 2 - 7 } & Wet season & -6.6 & -7.4 & 7.4 & 1.5 & 0.4 \\
\cline { 2 - 7 } & Annual & -1.6 & -2.9 & 12.9 & 12.1 & 11.1 \\
\hline \multirow{3}{*}{ TSS load (\%) } & Dry season & 24.3 & 25.8 & 44.6 & 70.3 & 59.3 \\
\cline { 2 - 7 } & Wet season & -6.3 & -7.1 & 9.3 & 3.5 & 2.0 \\
\cline { 2 - 7 } & Annual & -0.9 & -2.2 & 14.5 & 14.5 & 13.6 \\
\hline \multirow{3}{*}{ T-N load (\%) } & Dry season & 17.0 & 20.3 & 51.0 & 58.1 & 70.8 \\
\cline { 2 - 7 } & Wet season & -6.2 & -7.7 & 10.2 & 3.8 & 2.4 \\
\cline { 2 - 7 } & Annual & -3.8 & -6.7 & 13.0 & 9.8 & 8.4 \\
\hline \multirow{3}{*}{ T-P load (\%) } & Dry season & 21.5 & 20.3 & 70.6 & 93.7 & 96.6 \\
\cline { 2 - 7 } & Wet season & -5.0 & -3.8 & 8.2 & 4.0 & 4.5 \\
\cline { 2 - 7 } & Annual & -3.3 & -3.5 & 14.1 & 11.5 & 11.8 \\
\hline
\end{tabular}

Eventually, an accumulated effect of both climate change and land-use change will derive an increase in the seasonal and annual streamflow, and water quality components, as shown in the last two columns of Table 6. Additionally, the simulation results indicated that the streamflow and water 
quality parameters are more sensitive to land-use change than climate change. The findings here are similar to the results obtained from previous studies on the impact of climate and land-use changes, such as Wang et al. [12] and Fu et al. [25].

\section{Conclusions}

In this study, the segregated and aggregated effects of climate change and land-use change on streamflow and water quality (TSS, T-N, and T-P loads) in the La Buong River Basin located in Southern Vietnam were considered and evaluated using the SWAT model. The calibration and validation results of streamflow and water quality components insist on the efficiency and reliability of the SWAT model to evaluate hydrological processes under the environment changes in the study area.

Climate change leads to a decrease in the annual and wet-season streamflow and water quality, but an increase in those in dry seasons. Land-use change causes significant increases in annual and seasonal streamflow and TSS, T-N, and T-P loads. Analyses of the aggregated impacts of changing climate and land use indicate that the separated impacts of these changes on streamflow and water quality cannot be compensated by each other. Because the streamflow and water quality components are more sensitive to land-use change than climate change. This emphasizes that spatial land-use planning should be carefully considered in local integrated water resources management.

Eventually, the results obtained from this study can provide useful information to analyze, evaluate, and utilize for water resources distribution in different drivers under the effects of land-use and/or climate changes in the study region.

Author Contributions: Conceptualization, D.N.K. and V.T.N.; methodology, D.N.K. and V.T.N.; software, T.T.S. and P.T.T.N.; validation, D.N.K., T.T.S. and P.T.T.N.; formal analysis, D.N.K. and V.T.N.; investigation, D.N.K., T.T.S. and P.T.T.N.; data curation, T.T.S. and P.T.T.N.; writing-original draft preparation, D.N.K. and T.T.S.; writing-review and editing, V.T.N.; visualization, D.N.K., T.T.S.; supervision, V.T.N.; project administration, T.T.S.; funding acquisition, V.T.N.

Funding: This research is funded by Ho Chi Minh City's Department of Science and Technology (HCMC-DOST) and the Institute for Computational Science and Technology (ICST) under grant number 31/2017/HD-KHCNTT.

Acknowledgments: The authors would like to thank the anonymous reviewers for their valuable and constructive comments to improve our manuscript.

Conflicts of Interest: The authors declare no conflict of interest.

\section{References}

1. IPCC. Global Warming of $1.5^{\circ} \mathrm{C}$ : An IPCC Special Report on the Impacts of Global Warming of $1.5^{\circ} \mathrm{C}$ above Pre-Industrial Levels and Related Global Greenhouse Gas Emission Pathways, in the Context of Strengthening the Global Response to the Threat of Climate Change, Sustainable Development, and Efforts to Eradicate Poverty; Working Group I Technical Support Unit: Bern, Switzerland, 2018; ISBN 978-92-9169-151-7.

2. Elfert, S.; Bormann, H. Simulated impact of past and possible future land use changes on the hydrological response of the Northern German lowland 'Hunte' catchment. J. Hydrol. 2010, 383, 245-255. [CrossRef]

3. Tu, J. Combined impact of climate and land use changes on streamflow and water quality in eastern Massachusetts, USA. J. Hydrol. 2009, 379, 268-283. [CrossRef]

4. Talib, A.; Randhir, T.O. Climate change and land use impacts on hydrologic processes of watershed systems. J. Water Clim. Chang. 2017, 8, 363-374. [CrossRef]

5. Shrestha, S.; Bhatta, B.; Shrestha, M.; Shrestha, P.K. Integrated assessment of the climate and landuse change impact on hydrology and water quality in the Songkhram River Basin, Thailand. Sci. Total Environ. 2018, 643, 1610-1622. [CrossRef] [PubMed]

6. Setyorini, A.; Khare, D.; Pingale, S.M. Simulating the impact of land use/land cover change and climate variability on watershed hydrology in the Upper Brantas basin, Indonesia. Appl. Geomatics 2017, 9, 191-204. [CrossRef]

7. Huyen, N.T.; Tu, L.H.; Tram, V.N.Q.; Minh, D.N.; Liem, N.D.; Loi, N.K. Assessing the impacts of climate change on water resources in the Srepok watershed, Central Highland of Vietnam. J. Water Clim. Chang. 2017, 8, 524-534. [CrossRef] 
8. Ngo, T.S.; Nguyen, D.B.; Rajendra, P.S. Effect of land use change on runoff and sediment yield in Da River Basin of Hoa Binh province, Northwest Vietnam. J. Mt. Sci. 2015, 12, 1051-1064. [CrossRef]

9. Thai, T.H.; Thao, N.P.; Dieu, B.T. Assessment and Simulation of Impacts of Climate Change on Erosion and Water Flow by Using the Soil and Water Assessment Tool and GIS: Case Study in Upper Cau River basin in Vietnam. Vietnam J. Earth Sci. 2017, 39, 376-392. [CrossRef]

10. Khoi, D.N.; Suetsugi, T. The responses of hydrological processes and sediment yield to land-use and climate change in the Be River Catchment, Vietnam. Hydrol. Process. 2014, 28, 640-652. [CrossRef]

11. Wang, J.; Hiroshi, I.; Ning, S.; Khujanazarov, T.; Yin, G.; Guo, L. Attribution Analyses of Impacts of Environmental Changes on Streamflow and Sediment Load in a Mountainous Basin, Vietnam. Forests 2016, 7, 30. [CrossRef]

12. Wang, R.; Kalin, L.; Kuang, W.; Tian, H. Individual and combined effects of land use/cover and climate change on Wolf Bay watershed streamflow in southern Alabama. Hydrol. Process. 2014, 28, 5530-5546. [CrossRef]

13. Tan, M.L.; Gassman, P.W.; Srinivasan, R.; Arnold, J.G.; Yang, X. A Review of SWAT Studies in Southeast Asia: Applications, Challenges and Future Directions. Water 2019, 11, 914. [CrossRef]

14. Neitsch, A.L.; Arnold, J.G.; Kiniry, J.R.; Williams, J.R. Soil and Water Assessment Tool Theoretical Documentation Version 2009; Texas, A \& M University: College Station, TX, USA, 2011.

15. Khoi, D.N.; Thom, V.T. Parameter uncertainty analysis for simulating streamflow in a river catchment of Vietnam. Glob. Ecol. Conserv. 2015, 4, 538-548. [CrossRef]

16. Khoi, D.N.; Thom, V.T.; Quang, C.N.X.; Phi, H.L. Parameter uncertainty analysis for simulating streamflow in the upper Dong Nai river basin. La Houille Blanche 2017, 14-23. [CrossRef]

17. Moriasi, D.N.; Gitau, M.W.; Pai, N.; Daggupati, P. Hydrologic and Water Quality Models: Performance Measures and Evaluation criteria. Trans. ASABE 2015, 58, 1763-1785.

18. Semenov, M.; Stratonovitch, P. Use of multi-model ensembles from global climate models for assessment of climate change impacts. Clim. Res. 2010, 41, 1-14. [CrossRef]

19. Bian, H.; Lü, H.; Sadeghi, A.; Zhu, Y.; Yu, Z.; Ouyang, F.; Su, J.; Chen, R. Assessment on the Effect of Climate Change on Streamflow in the Source Region of the Yangtze River, China. Water 2017, 9, 70. [CrossRef]

20. Kumar, D.; Arya, D.S.; Murumkar, A.R.; Rahman, M.M. Impact of climate change on rainfall in Northwestern Bangladesh using multi-GCM ensembles. Int. J. Climatol. 2014, 34, 1395-1404. [CrossRef]

21. Abbaspour, K.C. SWAT-CUP: SWAT Calibration and Uncertainty Programs-A User Manual; Swiss Federal Institute of Aquatic Science and Technology: Dübendorf, Switzerland, 2015.

22. Sam, T.T.; Khoi, D.N.; Thao, N.T.T.; Nhi, P.T.T.; Quan, N.T.; Hoan, N.X.; Nguyen, V.T. Impact of climate change on meteorological, hydrological and agricultural droughts in the Lower Mekong River Basin: A case study of the Srepok Basin, Vietnam. Water Environ. J. 2018, 33. [CrossRef]

23. Dimotta, A.; Cozzi, M.; Romano, S.; Lazzari, M. Soil loss, productivity and cropland values gis-based analysis and trends in the Basilicata region (southern Italy) from 1980 to 2013. In International Conference on Computational Science and Its Applications; Gervasi, O., Ed.; Springer International Publishing: Cham, Switzerland, 2016; pp. 29-45.

24. Dimotta, A.; Lazzari, M.; Cozzi, M.; Romano, S. Soil erosion modelling on arable lands and soil types in Basilicata, Southern Italy. In International Conference on Computational Science and Its Applications; Gervasi, O., Ed.; Springer International Publishing: Cham, Switzerland, 2017; pp. 57-72.

25. Fu, Q.; Shi, R.; Li, T.; Sun, Y.; Liu, D.; Cui, S.; Hou, R. Effects of land-use change and climate variability on streamflow in the Woken River basin in Northeast China. River Res. Appl. 2019, 35, 121-132. [CrossRef]

(C) 2019 by the authors. Licensee MDPI, Basel, Switzerland. This article is an open access article distributed under the terms and conditions of the Creative Commons Attribution (CC BY) license (http://creativecommons.org/licenses/by/4.0/). 